UTILITY: Jurnal IImiah Pendidikan dan Ekonomi

Volume 3, No. 1, Februari 2019: Page 1-14

ISSN 2549-1377 (Print) || ISSN 2549-1385 (Online)

Available online at http://journal.stkipnurulhuda.ac.id/index.php/utility

\title{
PENGARUH LITERASI EKONOMI DAN GAYA HIDUP TERHADAP PERILAKU KONSUMTIF MAHASISWA PENDIDIKAN EKONOMI STKIP PGRI TULUNGAGUNG
}

\author{
Riski Puryasari ${ }^{1}$ \\ Mahasiswa Prodi Pendidikan Ekonomi SKIP PGRI Tulungagung \\ JL. Mayor Sujadi Timur No 7 Tulungagung \\ Email:rpuryasari@gmail.com
}

\begin{abstract}
Abstrak
Penelitian ini bertujuan untuk membuktikan (1) Pengaruh Literasi Ekonomi terhadap Perilaku konsumtif, (2) Pengaruh Gaya Hidup terhadap Perilaku konsumtif (3) Pengaruh literasi ekonomi dan gaya hidup terhadap perilaku konsumtif mahasiswi pendidikan ekonomi STKIP STKIP PGRI Tulungagung. Metode yang digunakan adalah metode kuantitatif.Penelitian ini dianalisa dengan menggunakan analisa regresi berganda.Populasi penelitian berjumlah 132 orang.Pengambilan sampel menggunakan proportional random sampling dengan sampel sebanyak 87 mahasiswi.Pengumpulan data menggunakan angket dengan kuesioner terbuka dan tertutup. Hasil penelitian menunjukkan bahwa: 1 . Nilai $t_{\text {hitung }}(0,486)<t_{\text {tabel }}(1,994)$ dan nilai signifikansi $0,248>0,05$ maka Hoditerima dan $\mathrm{H}_{1}$ ditolak, berarti tidak terdapat pengaruh literasi ekonomi terhadap perilaku konsumtif mahasiswi 2. Nilai $t_{\text {hitung }} t_{\text {hitung }}(5.612)$ $>\mathrm{t}_{\text {tabel }}$ (1.988) dan nilai signifikansi $0,000<0,05$ maka $\mathrm{H} 2$ diterima dan Ho2 ditolak, berarti terdapat pengaruh gaya hidup terhadap perilaku konsumtif mahasiswi; 3.Berdasarkan hasil analisis regresi linier berganda dapat diperoleh suatu persamaan linier yaitu $\mathrm{Y}=-4.227+$ $0,192 \mathrm{X}_{1}+0,765 \mathrm{X}_{2}$ yang artinya perilaku konsumtif mahasiswi dipengaruhi oleh gaya hidup, sedangkan untuk literasi ekonomi tidak mempengaruhi perilaku konsumtif mahasiswi Program Pendidikan Ekonomi di STKIP PGRI Tulungagung
\end{abstract}

Kata kunci: literasi ekonomi, gaya hidup, perilaku konsumtif.

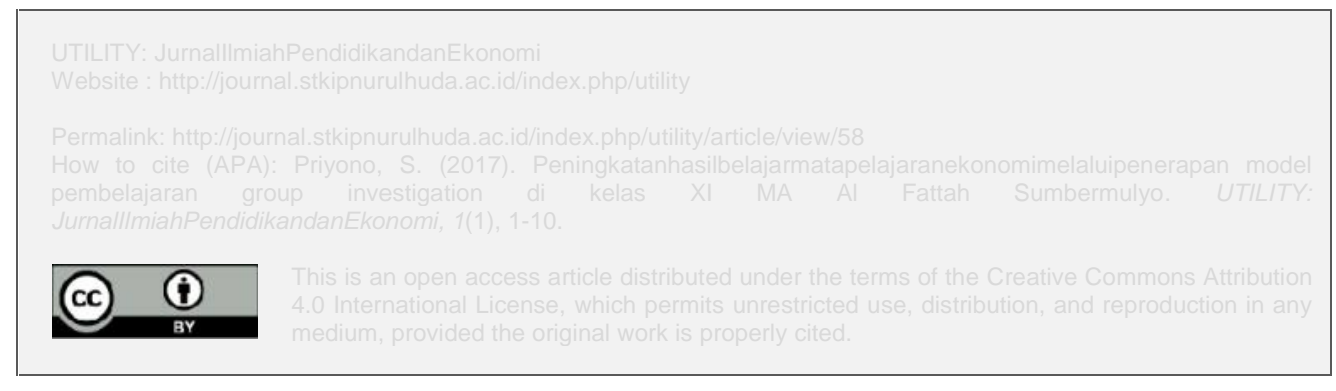




\section{PENDAHULUAN}

Bagi sebagian besar remaja yang berstatus mahasiswa, masa kuliah adalah masa pertama mereka mengelola keuangannya sendiri tanpa adanya pengawasan dari orang tua (Sabri et al, 2008 dalam Margaretha \& Pambudhi, 2015). Remaja inilah yang menjadi salah satu target pasar, dimana pasar melihat peluang akan gaya hidup remaja saat ini yang gemar mengikuti tren. Remaja cenderung mengutamakan keinginan dibanding kebutuhannya meskipun sebenarnya hal tersebut bukanlah sesuatu yang begitu dibutuhkan..Mahasiswa atau individu yang disebut remaja ini harus bisa mengelola keuangannya dengan baik dan harus bisa bertanggung jawab atas keputusan yang telah mereka perbuat.Permasalahan keuangan yang banyak muncul pada mahasiswa adalah banyak dari mereka yang tidak memiliki pendapatan, sebagian dari mereka masih bergantung kepada orang tuanya dan beberapa dari suaminya yang berstatus sudah menikah. Selain itu, sikap boros dari mahasiswa juga merupakan permasalahan yang sangat sering dihadapi.

Mahasiswa dikenal sebagai individu berpendidikan yang oleh masyarakat oleh karena itu sudah semestinya memiliki kontrol diri dalam melakukan kegiatan konsumtif, terlebih bagi mahasiswa dengan jurusan Ekonomi yang mempunyai pengetahuan lebih akan ilmu Ekonomi, ilmu yang diperoleh hendaknya diterapkan dalam kehidupan sehari-hari, Hilgard (2001) mengungkapkan bahwa setelah belajar tentang ilmu ekonomi mahasiswa tidak hanya mengerti tentang arti dan makna ekonomi melainkan terbentuk sikap dan nilai sebagai manusia yang rasional yang awalnya pemahaman dari laboratorium (sekolah) dan di aplikasikan dalam kehidupan sehari-hari (Hilgard, 2001 dalam Iqomudin, 2017).

Ilmu ekonomi berperan penting dalam kehidupan ekonomi setiap manusia, ilmu ekonomi akan mengatur prinsip kebutuhan pokok masyarakat, seseorang dengan pengetahuan Ekonomi akan dapat mengatur dan mengelola kondisi ekonomi atau keuangannya berdasarkan pengetahuannya. Kemampuan dalam mengatur dan mengelola kondisi ekonomi ini disebut dengan literasi Ekonomi, untuk memiliki literasi ekonomi yang memadai mahasiswa perlu memahami ilmu ekonomi ${ }^{3}$.

Pada dasarnya mahasiswa berasal dari daerah yang berbeda dengan kelas sosial yang beragam, oleh sebab itu ilmu ekonomi penting untuk dipelajari sebagai kontrol manusia berperilaku konsumtif, Perilaku konsumtif 
yang dilakukan terus menerus tanpa kontrol dapat menimbulkan dampak pada masa depan. Dampak negatif dari perilaku konsumtif yaitu pola hidup boros yang dapat mengurangi kesempatan menabung dan cenderung tidak memikirkan kebutuhan yang akan dating nantinya ${ }^{4}$

Hal tersebut di dukung dengan ungkapan beberapa mahasiswi program pendidikan ekonomi di STKIP PGRI Tulungagung, Firda Dalina (4A) menyatakan dirinya merasa lumayan boros padahal sudah bekerja dan masih di bantu biaya orang tua, seringkali pendapatannya digunakan untuk membeli paket internet dan produk skincare, namun tidak memiliki buku penunjang perkuliahan, Linanda (6A) juga mengungkapkan bahwa dirinya cukup boros dengan statusnya yang sudah bekerja,uangnya seringkali dipergunakan belanja berbagai kebutuhan dan tidak lupa juga skincare, namun Linanda tidak memiliki buku penunjang perkuliahan, hal tersebut sama halnya seperti yang diungkapkan Mey Kusuma (6B) yang masih dibiayai orang tua menyatakan dirinya juga termasuk mahasiwi yang lumayan boros dan seringkali ingin segera memakai uangnya saat memiliki uang yang lebih, entah untuk jalanjalan atau sekedar membeli perlengkapan kuliah maupun kosmetik dan juga tidak memiliki buku penunjang perkuliahan.

Pernyataan tersebut menyimpulkan bahwa mahasiswi cenderung berperilaku konsumtif, dan cenderung mengabaikan kebutuhan utama mereka yang lebih penting sebagai mahasiwi seperti buku penunjang perkuliahan. Perempuan memang merupakan gender yang sangat sensitif dengan gaya hidup yang berlebihan sehingga seorang perempuan harus mempunyai pengetahuan dasar ekonomi.

Mahasiswa sebagai generasi muda tidak hanya akan menghadapi tantangan ekonomi yang semakin meningkat, tetapi mereka lebih cenderung harus menanggung risiko keuangan di masa depan yang lebih dari orang tua mereka saat ini (Lusardi, dalam Widayati, 2017). Oleh karena itu literasi ekonomi penting untuk dimiliki dan diterapkan dalam gaya hidup setiap individu agar individu lebih cerdas untuk memilih dan membuat keputusan dalam berperilaku konsumtif terlebih mahasiswa sebagai calon manusia di masa depan.

Penelitian terdahulu mengungkapkan bahwa literasi ekonomi dan hidup gaya hidup secara bersama-sama berpengaruh secara signifikan terhadap perilaku konsumtif mahasiswa jurusan pendidikan ekonomi UNDIKSHA ${ }^{3}$, 
Hasil penelitian ini menunjukan literasi ekonomi berpengaruh negatif terhadap perilaku konsumtif sebesar -2,470, gaya hidup berpengaruh positif terhadap perilaku konsumtif sebesar 12,839, literasi Ekonomi dan gaya hidup berpengaruh terhadap perilaku konsumtif sebesar 85,453. Penelitian lain yang relevan menunjukan literasi ekonomi dan gaya hidup juga memiliki pengaruh yang signifikan terhadap perilaku konsumtif pada mahasiswa Pendidikan Ekonomi STKIP YPM Bangko ${ }^{6}$. Hasil penelitian ini menunjukan literasi ekonomi berpengaruh negatif terhadap perilaku konsumtif. Hasil penelitian ini menunjukan literasi ekonomi berpengaruh negatif terhadap perilaku konsumtif sebesar 6,869, gaya hidup berpengaruh positif terhadap perilaku konsumtif sebesar 3,857. Sedangkan literasi ekonomi dan gaya hidup bepengaruh signifikan terhadap perilaku konsumtif sebesar 6,869.

Berdasarkan latar belakang diatas penulis ingin meneliti akan pengaruh literasi ekonomi dan gaya hidup terhadap perilaku konsumtif mahasiswi Program Studi Pendidikan Ekonomi STKIP PGRI Tulungagung.

\section{METODE}

Jenis penelitian ini menggunakan jenis penelitian kuantitatif korelasi, yang menguji pengaruh literasi ekonomi dangaya hidup terhadap perilaku konsumtif. Menurut Arikunto (2013, hal.4) penelitian korelasi atau penelitian korelasional adalah penelitian yang dilakukan oleh peneliti untuk mengetahui tingkat hubungan antara dua variabel atau lebih, tanpa melakukan perubahan, tambahan atau manipulasi terhadap data yang memang sudah ada.

Pengumpulan data penelitian ini menggunakan angket tertutup dan terbuka, dengan menggunakan teknik pengambilan sampel proportional random sampling yaitu pengambilan sampel secara acak pada tiap-tiap kelas secara proporsional. Teknik analisis menggunakan analisis regresi linier berganda dengan kriteria uji t dan uji f. Uji f digunakan untuk menguji signifikansi variabel literasi ekonomi dan gaya hidup terhadap perilaku konsumtif secara simultan. Sedangkan uji $t$ digunakan untuk menguji signifikansi variabel literasi ekonomi dan gaya hidup terhadap perilaku konsumtif secara parsial.

Adapun yang menjadi indikator dalam penelitian ini adalah :Pertama Literasi Ekonomi (X1) meliputi pemahaman terhadap kebutuhan, pemahaman 
terhadap kelangkaan, kemampuan menganalisis tingkat harga terhadap kecenderungan menabung, pendapatan individu, dan penegertian akan cost and benefit. Kedua gaya hidup (X2) meliputi kegiatan, minat, dan pandangan. Sedangkan perilaku konsumtif (Y) meliputi meliputi membeli karena imingiming hadiah, membeli karena kemasan produk menarik, membeli untuk menjaga penamilan diri dari gengsi, membeli karena potongan harga, membeli demi menjaga symbol status, dan Pembelian impulsive.

\section{HASIL DAN PEMBAHASAN}

\section{Hasil}

\section{Uji Asumsi Klasik}

\section{a.Uji Normalitas}

Dari penelitian ini, perhitungan uji normalitas menggunkan metode One Sample Kolmogorov Smirnov diperoleh nilai Signifikansi.Dari tabel 4.8 dapat disebutkan nilai Asymp. Signifikansi (2-tailed) sebesar 0,771>0,05.

Tabel 1. Uji Normalitas

One-Sample Kolmogorov-Smirnov Test

\begin{tabular}{|ll|r|}
\hline & & \multicolumn{2}{|c|}{$\begin{array}{c}\text { Studentized Deleted } \\
\text { Residual }\end{array}$} \\
\hline $\mathrm{N}$ & & 87 \\
Normal Parameters ${ }^{\mathrm{a}}$ & Mean & -.0061161 \\
& Std. Deviation & 1.02035770 \\
Most Extreme & Absolute & .071 \\
Differences & Positive & .046 \\
& Negative & -.071 \\
Kolmogorov-Smirnov Z & & .664 \\
Asymp. Sig. (2-tailed) & & .771 \\
\hline a. Test distribution is Normal. & \\
\hline
\end{tabular}

Berdasarkan data tersebut, dapat disimpulkan bahwa data yang peneliti peroleh dalam penelitian ini berdistribusi normal dan lolos uji normalitas. 


\section{b.Uji Linieritas}

Tabel 2. Rangkuman Uji Linieritas

ANOVA Table

\begin{tabular}{|c|c|c|c|c|c|c|c|}
\hline & & & $\begin{array}{l}\text { Sum of } \\
\text { Squares }\end{array}$ & df & $\begin{array}{l}\text { Mean } \\
\text { Square }\end{array}$ & F & Sig. \\
\hline \multirow{5}{*}{$\begin{array}{l}\text { Perilaku } \\
\text { Konsumtif * } \\
\text { Litersi } \\
\text { Ekonomi }\end{array}$} & Between & (Combined) & 1561.414 & 18 & 86.745 & 1.807 & .042 \\
\hline & Groups & Linearity & 552.001 & 1 & 552.001 & 11.502 & .001 \\
\hline & & $\begin{array}{l}\text { Deviation from } \\
\text { Linearity }\end{array}$ & 1009.413 & 17 & 59.377 & 1.237 & .261 \\
\hline & \multicolumn{2}{|c|}{ Within Groups } & 3263.506 & 68 & 47.993 & & \\
\hline & \multicolumn{2}{|l|}{ Total } & 4824.920 & 86 & & & \\
\hline
\end{tabular}

Dari tabel 2 hasil uji linieritas dalam penelitian ini, yakni kombinasi kolom Signifikansi pada baris Linearity literasi ekonomi terhadap perilaku konsumtif sebesar 0,001 < 0,05 yang berarti jika nilai Signifikansi lebih kecil dari 0,05 dapat disimpulkan bahwa data tersebut memenuhi syarat linier.

\section{c. Uji Multikolonieritas}

Dikatakan tidak terjadi multikolinieritas apabila nilai Tolerance $>0,1$ dan nilai VIF < 10 dengan hasil sebagai berikut:

\section{Tabel 3.Uji Multikolinieritas}

Coefficients $^{\mathrm{a}}$

\begin{tabular}{|r|r|r|r|r|r|r|r|}
\hline & \multicolumn{2}{|c|}{$\begin{array}{c}\text { Unstandardized } \\
\text { Coefficients }\end{array}$} & $\begin{array}{c}\text { Standardized } \\
\text { Coefficients }\end{array}$ & $\mathrm{t}$ & \multicolumn{2}{|c|}{ Sig. } & \multicolumn{2}{|c|}{$\begin{array}{c}\text { Collinearity } \\
\text { Statistics }\end{array}$} \\
\cline { 2 - 9 } Model & \multicolumn{1}{c|}{$\mathrm{B}$} & Std. Error & Beta & & & Tolerance & VIF \\
\hline $1 \quad \begin{array}{l}\text { (Constant) } \\
\text { Literasi } \\
\text { Ekonomi } \\
\text { Gaya Hidup }\end{array}$ & -4.227 & 6.299 & & -.671 & .504 & & \\
& .192 & .165 & .112 & 1.163 & .248 & .825 & 1.212 \\
& .136 & .541 & 5.612 & .000 & .825 & 1.212 \\
\hline
\end{tabular}

a. Dependent Variable: Perilaku Konsumtif

Sumber: Data Olahan Peneliti (2019)

Dari tabel 3 hasil di atas menunjukkan bahwa nilai Tolerance literasi ekonomi dan gaya hidup lebih dari 0,1 . Selanjutnya nilai VIF untuk ketiga 
variabel kurang dari 10, dengan demikian dapat disimpulkan bahwa model regresi dalam penelitian ini tidak terjadi multikolinieritas.

\section{d. Uji Heterokedastisitas}

\section{Tabel 4.Uji Heteroskedastisitas}

\begin{tabular}{|l|r|r|r|r|r|}
\hline \multirow{2}{*}{ Model } & \multicolumn{2}{|c|}{$\begin{array}{c}\text { Unstandardized } \\
\text { Coefficients }\end{array}$} & $\begin{array}{r}\text { Standardized } \\
\text { Coefficients }\end{array}$ & & \\
\cline { 2 - 5 } & \multicolumn{1}{|c|}{ B } & Std. Error & Beta & \multicolumn{1}{c|}{$\mathrm{t}$} & Sig. \\
\hline $1 \quad$ (Constant) & 11.298 & 3.666 & & 3.082 & .003 \\
$\quad \begin{array}{l}\text { Literasi } \\
\text { Ekonomi }\end{array}$ & -.101 & .096 & -.124 & -1.052 & .296 \\
Gaya Hidup & -.069 & .079 & -.102 & -.868 & .388 \\
\hline
\end{tabular}

a. Dependent Variable: RES2

Dari tabel 4.12 dapat dilihat bahwa nilai Signifikansi pada X1 sebesar 0,296 yang artinya nilai Signifikansi >0,05 sehingga tidak terjadi gejala heteroskedastisitas. Untuk nilai X2 nilai Signifikansi sebesar 0,388 dimana nilai Signifikansi $>0,05$ yang artinya juga tidak terjadi gejala heteroskedastisitas.

\section{Analisis Data}

\section{a. Regresi Linier Berganda}

Regresi linier berganda digunakan untuk tujuan mengetahui pengaruh literasi ekonomi dan gaya hidup terhadap perilaku konsumtif.Berdasarkan hasil analisis regresi linier berganda di atas dapat diperoleh suatu persamaan linier yaitu $\mathrm{Y}=-4.227+0,192 \mathrm{X}_{1}+0,765 \mathrm{X}_{2}$ secara berturut-turut dari atas bisa dilihat pada baris Unstandarized Coefficients B pada tabel Coefficients.

\section{b. Koefisien Determinasi}

Koefisien determinan yaitu suatu bilangan yang real diperoleh dari suatu proses $R$ Square atau $\mathrm{R}^{2}$, yaitu menunjukkan koefisien determinasi. Angka ini akan diubah dalam bentuk persen artinya prosentase sumbangan pengaruh variabel independen terhadap variabel dependen. 
Dalam penelitian ini, indeks korelasi untuk $\left(\mathrm{Y}^{*} \mathrm{X}_{1}, \mathrm{X}_{2}\right)$ adalah 0,597 jika besaran nilai $\mathrm{R}$ dicocokan dengan interprestasi pada tabel interpetasi koefisien korelasi maka dapat ditentukan hubngan antara voolariabel X1 dan X2 terhadap Y cukup kuat. Sedangkan indeks determinasi untuk X1 dan X2 terhadap Y berdasarkan nilai Adjusted R square yakni 0,341. Nilai Adjusted R square dikalikan $100 \%$ menjadi $34,1 \%$ sedangkan untuk sisanya sebesar $65,9 \%$ dipengaruhi oleh faktor lain di luar penelitian ini.

Jadi konstribusi literasi ekonomi dan gaya hidup terhadap perilaku konsumtif mahasiswa Program Studi Pendidikan Ekonomi angkatan tahun di STKIP PGRI Tulungagung sebesar 34,1\%.

\section{Pengujian Hipotesis Statistik}

\section{a. Uji t}

Uji t digunakan untuk mengetahui apakah variabel-variabel independen secara parsial berpengaruh nyata atau tidak terhadap variabel dependen.Dalam penelitian ini pengaruh literasi ekonomi dan gaya hidup terhadap perilaku konsumtif mahasiswa Program Studi Pendidikan Ekonomi STKIP PGRI Tulungagung secara parsial sebagai berikut:

Tabel 5. Hasil Uji t

Coefficients ${ }^{\mathrm{a}}$

\begin{tabular}{|c|c|c|c|c|c|}
\hline \multirow[b]{2}{*}{ Model } & \multicolumn{2}{|c|}{$\begin{array}{c}\text { Unstandardized } \\
\text { Coefficients }\end{array}$} & $\begin{array}{l}\text { Standardized } \\
\text { Coefficients }\end{array}$ & $\mathrm{T}$ & Sig. \\
\hline & B & Std. Error & Beta & & \\
\hline $1 \quad$ (Constant) & -4.227 & 6.299 & & -.671 & .504 \\
\hline Literasi & .192 & .165 & .112 & 1.163 & .248 \\
\hline Ekonomı & & & & & \\
\hline Gaya Hidup & .765 & .136 & .541 & 5.612 & .000 \\
\hline
\end{tabular}

a. Dependent Variable: Perilaku

Konsumtif

Dari tabel 4.15 menunjukkan hasil analisis data pengaruh literasi ekonomi terhadap perilaku konsumtif mahasiswa program studi Pendidikan Ekonomi di STKP PGRI Tulungagung menunjukkan bahwa nilai $\mathrm{t}$ hitung $(1,163)<\mathrm{t}$ tabel $(1.988)$ dan nilai Signifikansi 0,248>0,05 maka Hoditerima dan $\mathrm{H}_{1}$ ditolak, berarti tidak terdapat pengaruh literasi ekonomi terhadap 
perilaku konsumtif mahasiswa Program Studi Pendidikan Ekonomi di STKIP PGRI Tulungagung.

Selanjutnya hasil analisis data gaya hidup terhadap perilaku konsumtif mahasiswa program studi Pendidikan Ekonomi di STKP PGRI Tulungagung menunjukkan bahwa nilai $\mathrm{t}_{\text {hitung }}(5.612)>\mathrm{t}_{\text {tabel }}$ (1.988) dan nilai Signifikansi $0,000<0,05$ maka $\mathrm{H}_{2}$ diterima dan Hoditolak, berarti terdapat pengaruh mahasiswa Program Studi Pendidikan gaya hidup terhadap perilaku konsumtif mahasiswa program studi pendidikan ekonomi di STKIP PGRI Tulungagung.

\section{b. Uji f}

Uji $\mathrm{F}$ digunakan untuk menghitung pengaruh secara simultan literasi ekonomi dan gaya hidup terhadap perilaku konsumtif mahasiswa Program Studi Pendidikan Ekonomi di STKIP PGRI Tulungagung dengan hasil sebagai berikut:

\section{Tabel 6.Uji F (Simultan)}

\section{ANOVA $^{\mathrm{b}}$}

\begin{tabular}{|r|r|r|r|r|r|}
\hline \multicolumn{1}{|c|}{ Model } & Sum of Squares & df & Mean Square & F & Sig. \\
\hline $1 \quad$ Regression & 1717.333 & 2 & 858.666 & 23.210 & $.000^{\mathrm{a}}$ \\
Residual & 3107.587 & 84 & 36.995 & & \\
Total & 4824.920 & 86 & & & \\
\hline
\end{tabular}

a. Predictors: (Constant), Gaya Hidup, Literasi Ekonomi

b. Dependent Variable: Perilaku Konsumtif

Dari tabel 4.16 menunjukkan bahwa $\mathrm{F}_{\text {hitung }}(23,210)>\mathrm{F}_{\text {tabel }}(3.11)$ dan nilai signifikan 0,000 $<0,05$ maka Ho ditolak dan $\mathrm{H}_{3}$ diterima. Dari analisis tersebut dapat ditarik kesimpulan bahwa terdapat pengaruh yang signifikansi antara variabel literasi ekonomi dan gaya hidup terhadap perilaku konsumtif mahasiswa Program Studi Pendidikan Ekonomi di STKIP PGRI Tulungagung.

\section{Pembahasan}

\section{INTERPRETASI HASIL PENELITIAN}

\section{a. Pengaruh literasi ekonomi (X1) terhadap perilaku konsumtif (Y)}


Berdasarkan hasil pertanyaan terbuka pada angket penelitian ditemukan beberapa hal sebagai berikut;

1) Mahasiswi memperoleh pendapatan rata-rata dari bekerja dan sebagian besar masih diberi oleh orang tua.

2) Cara mahasiswi mengatur keuangan selama ini adalah dengan berusaha tidak membeli hal yang sekiranya tidak perlu

3) Kebutuhan remaja sekaligus mahasiswi seperti kuota data, kosmetik dan print atau photocopy

4) Kebutuhan yang lebih diutamakan sebagai mahasiswi seperti tugas atau perlengkapan kuliah yang mengeluarkan biaya

5) Mahasiswi memahami keterbatasan produk dalam pasar dann memberi contoh seperti sumber daya yang tidak dapat diperbaharui

6) Saat ini mahasiswi tidak memiliki tabungan dan sebagian mempunyai dalam bentuk uang yang disimpan sendiri

7) Alasan mahasiswi beranggapan perlu menabung sejak dini karena dapat digunakan dimasa depan

8) Untung rugi yang selalu dipertimbangkan mahasiswi saat transaksi adalah membeli barang saat diskon

9) Mahasiswi berusaha hidup sehemat mungkin kebanyakan menjawab tetap tidak sebagian menjawab kadang bias

10) Mahasiswi memikirkan manfaat yang didapat harus lebih besar dari biaya yang dikeluarkan dan menerapkannya saat proses transaksi jarang.

\section{b. Pengaruh gaya hidup(X2) terhadap perilaku konsumtif(Y)}

Berdasarkan hasil pertanyaan terbuka pada angket penelitian variabel gaya hidup ditemukan beberapa fakta sebagai berikut;

1) Cara mahasiswi memanfaatkan waktu luang yang positif adalah dengan membantu orang tua dan sebagian tidur

2) Cara membagi waktu kuliah dengan hal lain bagi mahasiswi adalah berdasarkan jadwal

3) Mahasiswi sering menghabiskan waktu diluar rumah selain saat jadwal kuliah sebagian rata-rata menjawab sering sebagian menjawab jarang

4) Alasan mahasiswi anda lebih suka berdiam diri dirumah karena tidak mempunyai uang untuk pergi jalan-jalan 
5) Kesempatan yang sering mahasiwi ditemui seperti kesempatan untuk bekerja

6) Hal yang diminati mahasiswi saat ini rata-rata menjawab fashion

7) Mahasiwi beranggapan tidak boleh ketinggalan jaman karena semua sudah serba maju

8) Perkembangan gaya hidup yang dipahami mahasiswi adalah hal yang sedang trend saat ini dan sebagian menjawab teknologi canggih

9) Mahasiswi merasa sangat mengikuti perkembangan jaman saat ini seperti mengikuti trend

10) Mahasiswi beranggapan tidak mempunyai gaya hidup seperti remaja ibu kota yang terkesan trendsenter dan hedonis.

Sedangkan untuk hasil pertanyaan terbuka pada angket penelitian variabel perilaku konsumtif ditemukan beberapa fakta sebagai berikut;

1) Mahasiwi akan membeli produk jika mendapat hadiah pembelian karena merasa tertarik

2) Mahasiswi membeli produk jika produk tersebut mendapat bonus pmbelian produk yang sama (buy one get one free) merasa hal itu cukup menguntungkan

3) Mahasiswi akan mencoba produk sejenis yang pernah dimiliki sebelumnya dengan brand yang berbeda rata-rata menjawab tidak karena sudah punya

4) Mahasiswi seringkali tergiur terhadap produk dengan kemasan menarik karena mahasisiwi menyukai produk dengan kemasan yang bagus dan menarik

5) Mahasiswi akan membeli produk yang sedang tren saat ini karena menyukai dan tertarik

6) Mahasiswi akan membeli produk jika teman-teman saya sudah punya, tapi saya belum punya rata-rata menjawab tidak karena tidak perlu sebagian menjawab akan membeli jika memang tertarik

7) Mahasiswi membeli suatu produk yang bagus agar tidak dipandang sebelah mata oleh orang lain karena prestige

8) Mahasiswi suka membeli barang yang sedang diskon karena beranggapan diskon merupakan kesempatan yang sayang untuk dilewatkan

9) Mahasiswi merasa membeli atau memakai barang brermerk akan membuat lebih percaya diri karena barang yang dibeli dan dipakai dirasa lebih berkualitas dan terlihat menonjol daripada yang lain 
10) Mahasiswi sering membeli sesuatu secara tiba-tiba yang tidak direncanakan sebelumnya karena perasaan tertarik

\section{SIMPULAN}

Berdasarkan pelaksanaan penelitian dan analisis data, serta kesesuaian dengan hipotesis dan rumusan masalah, maka dapat ditarik simpulan sebagai berikut:

1. Tidak terdapat pengaruh literasi ekonomi terhadap perilaku konsumtif mahasiswi Program Studi Pendidikan Ekonomi STKIP PGRI Tulungagung.

2. Terdapat pengaruh gaya hidup terhadap perilaku konsumtif mahasiswi Program Studi Pendidikan Ekonomi STKIP PGRI Tulungagung.

3. Berdasarkan hasil analisis regresi linier berganda dapat diperoleh suatu persamaan linier yaitu $\mathrm{Y}=-4.227+0,192 \mathrm{X}_{1}+0,765 \mathrm{X}_{2}$ dengan sumbangan sebesar 34,1\%. Artinya perilaku konsumtif mahasiswi dipengaruhi oleh gaya hidup dan literasi ekonomi. Akan tetapi untuk literasi ekonomi secara parsial tidak dapat mempengaruhi perilaku konsumtif mahasiswi Program Studi Pendidikan Ekonomi STKIP PGRI Tulungagung.

\section{SARAN}

Berdasarkan Berdasarkan hasil kesimpulan maka dapat diberikan saran bagi pihak yang berkepentingan dalam penelitian ini:

1. Bagi Mahasiswa

Hasil penenlitian ini diharapkan dapat menambah wawasan dan pengetahuan dalam hal literasi ekonomi dan gaya hidup yang sekiranya dapat diterapkan untuk membantu pengelolaan kegiatan konsumtif mahasiswa.

2. Bagi Akademisi

Hasil penelitian ini diharapkan dapat dijadikan tambahan referensi bukti empiris serta menjadi rekomendasi penelitian yang akan datang. 


\section{KETERBATASAN PENELITIAN}

Penelitian ini memiliki beberapa keterbatasan, diantaranya adalah :

1. Variabel pada penelitian ini terbatas pada literasi ekonomi, gaya hidup dan perilaku konsumtif mahasiswi.

2. Responden penelitian ini adalah mahasiswi prodi Ekonomi di STKIP PGRI Tulungagung sehingga hasil-hasil penelitian ini belum tentu dapat digeneralisir untuk kasus di luar Prodi Ekonomi STKIP PGRI Tulungagung yang memiliki karakteristik berbeda.

3. Respon yang relatif masih sedikit dari responden hal ini ditandai dengan adanya beberapa responden yang tidak langsung mengisi kuesioner pada saat dibagikan dan disamping itu banyak responden yang tidak menjawab pertanyaan terbuka yang ada pada kuisoner.

4. Terdapat hasil perhitungan statistic pengaruh literasi ekonomi terhadap perilaku konsumtif memiliki hasil yang tidak berpengaruh, sehingga untuk peneliti selanjutnya diharapkan dapat meneliti lebih dalam lagi faktorfaktor lain yang mampu mempengaruhi kesadaran konsumsi mahasiswi diluar literasi ekonomi dan gaya hidup.

\section{UCAPAN TERIMAKASIH}

Ucapan terimakasih ditujukan kepada SKIP PGRI Tulungagung yang telah memberikan kesempatan untuk melaksanakan penelitian dan Seluruh mahasiswa Ekonomi di SKIP PGMI Tulungagung yang berpartisipasi dalam penelitian yang penulis lakukan.

\section{REFERENSI}

Margaretha F, Pambudhi RA. Tingkat Literasi Keuangan Pada Mahasiswa S-1 Fakultas Ekonomi. J Manaj Dan Kewirausahaan. 2015;17(1):76-85. doi:10.9744/jmk.17.1.76

Kanserina D. Pengaruh Literasi Ekonomi dan Gaya Hidup Terhadap Perilaku Konsumtif Mahasiswa Jurusan Pendidikan Ekonomi UNDIKSHA 2015. J Jur Pendidik Ekon. 2015;5(1).

Saputri HM, Siswandari, Muchsini B. Jurnal "Tata Arta" UNS. Pengaruh

Financ Lit Terhadap Perilaku Konsumtif Siswa SMA Muhammadiyah 
Riski Puryasari ${ }^{1}$

Progr Khusus Kottabarat Surakarta. 2017;3(2):85-94.

Widayati I. Faktor-Faktor Yang Mempengaruhi Literasi Finansial Mahasiswa

Fakultas Ekonomi Dan Bisnis Universitas Brawijaya. J Akunt dan Pendidikan,. 2017;1(1):89-99. doi:10.25273/jap.v1i1.527

Angra Melina, Wulandari S. Pengaruh Literasi Ekonomi Dan Gaya Hidup

Terhadap Perilaku Konsumtif Mahasiswi Ekonomi STKIP YPM Bangko. Sci Journals Econ Educ. 2018;2(April):141-152.

Iqomudin MA. Pengaruh Literasi Ekonomi, Pendidikan Ekonomi Dalam Keluarga Dan Latar Belakang Sosial Ekonomi Orang Tua Terhadap Pengambilan Keputusan Berkonsumsi Pada Mahasiswa Pendidikan IPS Universitas Islam Negeri Maulana Malik Ibrahim Malang. 2017. 